\title{
PENGARUH PELAKSANAAN RISK BASED INTERNAL AUDITING TERHADAP PENCEGAHAN FRAUD
}

(Studi Kasus pada Audit Internal Kantor Inspeksi Bank BRI Wilayah Bandung)

\author{
Rozmita Dewi Yuniarti Rozali \\ Jabbaar Mohammad \\ jabbaarmohammad@ymail.com \\ (Universitas Pendidikan Indonesia)
}

\begin{abstract}
ABSTRAK
Penelitian ini bertujuan untuk mengetahui pengaruh pelaksanaan risk based internal auditing terhadap pencegahan fraud pada audit internal Kantor Inspeksi Bank BRI Wilayah Bandung. Sampel yang digunakan sebanyak 18 auditor internal di Kantor Inspeksi Bank BRI Wilayah Bandung metode sampling jenuh.Berdasarkan perhitungan analisis regresi sederhana diperoleh hasil bahwa setiap peningkatan pelaksanaan risk based internal auditing (X) akan mengakibatkan kenaikan pencegahan fraud (Y). Hal tersebut menunjukan terdapat pengaruh positif antara pelaksanaan risk based internal auditing terhadap pencegahan fraud pada audit internal Kantor Inspeksi Bank BRI Wilayah Bandung.
\end{abstract}

\section{PENDAHULUAN}

Akhir-Akhir ini banyak kasus-kasus fraud ditemukan di berbagai sektor seperti perbankan, BUMN, dan perpajakan. Survei yang dilakukan oleh Association of Certified Fraud Examiners (ACFE, 2013) menunjukan bahwa dari tahun ke tahun rata-rata organisasi selalu kehilangan 5\% dari pendapatannya karena fraud (korupsi, dll). Pada tahun 2013, Bank Indonesia telah melakukan investigasi terhadap 66 kasus dugaan tindak pidana perbankan / tipibank yang terjadi di bank umum maupun BPR di seluruh Indonesia. Dari jumlah tersebut sebanyak 23 kasus pada 15 bank telah dilaporkan oleh Bank Indonesia kepada penyidik. Dari jumlah kasus yang telah selesai diivestigasi tersebut, sebanyak 39 kasus $(59,09 \%)$ merupakan kasus dalam aktivitas perkreditan, tercatat beberapa kasus perkreditan antara lain kasus korupsi dana kredit pada tahun 2010 yaitu kasus kepala BRI Riung Bandung, kasus bermula dari kredit yang dikucurkan BRI kepada 88 orang PNS. Dalam permohonan kredit, 88 debitur dimintai fotocopy SK, padahal SK asli para pegawai menjadi jaminan di Bank Jabar Banten. Terdakwa akan membantu memperlicin permohonan dengan syarat-syarat tambahan yang dibebankan pada terdakwa. Termasuk memotong Rp 5 juta jika permohonan kredit terkabul dan hal tersebut diakui oleh Endang dipersidangan bahwa dirinya menerima uang dari para nasabah.Namun dia mengakui bahwa tidak semua nasabah memberi uang kepadanya.terdakwa dipidanakan dengan 
pasal 2 ayat 1, pasal 18 Undang-undang No 31 tahun 1999 tentang Tipikor (www.pikiran-rakyat.com). Dengan banyaknya kasus fraud yang ditemukan dalam kegiatan bisnis, seolah-olah praktik bisnis yang ada saat ini tidak dapat lagi dipercaya dan internal control tidak lagi dapat diandalkan untuk mencegah adanya fraud.

Salah satu hal yang memegang peranan penting dalam meningkatkan pencegahan fraud dari sebuah perusahaan adalah adanya peranan efektif dan efisien dari Satuan Pengendalian Internal atau yang sering disebut dengan Internal Audit. Pemahaman yang mendalam akan sebuah proses, teknik serta langkahlangkah dalam melakukan proses audit akan memberi dampak yang positif bagi perusahaan terutama dalam meminimalkan suatu risiko yang akan dihadapi oleh perusahaan. Association of Certified Fraud Examiners (ACFE) dalam laporannya yang berjudul Report to the Nation on Occupational Fraud and Abuse (2014 Global Fraud Study)menunjukan bahwa internal audit sangat berperan dalam pencegahan kecurangan. Sebagian besar fraud / kecurangan terungkap melalui tips atau informasi dari seseorang atau sekelompok orang, management review, dan melalui internal audit.

Bank senantiasa dihadapkan pada risiko-risiko yang melekat dalam setiap kegiatan usahanya.Risiko - risiko yang melekat tersebut dapat berasal dari kegiatan bank itu sendiri maupun dari perusahaan yang terkait dengan bank.Berdasarkan Peraturan Bank Indonesia No.5/8/PBI/2003 tanggal 2003 dan SEBI No.5/21/DPNP tanggal 29 September 2003, Bank Umum di Indonesia mulai Januari 2005 diwajibkan menerapkan manajemen risiko dalam pengelolaan banknya.Z. Dunil (2005:78), menjelaskan penerapan manajemen risiko pada bank umum membawa pengaruh yang signifikan terhadap cara kerja SKAI (Satuan Kerja Audit Internal). Bank umum yang telah menerapkan manajemen risiko secara penuh, artinya semua tahapan manajemen risiko sudah dilakukan oleh bank. Maka SKAI wajib pula mengikuti langkah banknya dengan merubah cara kerja SKAI dengan mempertimbangkan aspek risiko secara terencana dalam kegiatan audit yang dilakukan. SKAI segera memulai memanfaatkan proses manajemen risiko yang masih tergolong baru ini dalam pelaksanaan audit. Audit sudah harus dilaksanakan dengan berbasis risiko (Risk Based Audit). Z. Dunil (2005:18), menjelaskan audit internal berbasis resiko adalah audit yang difokuskan dan diprioritaskan pada risiko bisnis dan prosesnya serta pengendalian terhadap risiko yang dapat terjadi. Choirul(2010) dalam penelitiannya berpendapat, terdapat perubahan filosofi audit internal dari paradigma lama menuju paradigma baru.Perubahan ini ditandai dengan pergeseran orientasi dan peran profesi auditor internal.Menurut paradigma lama, auditor internal lebih berorientasi untuk memberikan kepuasan kepada jajaran pimpinan.Dalam masa sekarang ini, fungsi auditor internal tidak dapat lagi hanya berperan sebagai watchdog, namun harus dapat berperan sebagai mitra bagi manajemen. 
Albercht, (2012). Having a good system of internal control is the single most effective tool in preventing and detecting fraud. Memiliki sistem internal kontrol yang baik merupakan salah satu alat yang efektif dalam mencegah dan mendeteksi fraud.Singleton, (2010).Cara pencegahan tindakan fraud yang paling efektif adalah perubahan perilaku dan budaya organisasi yang memberikan perhatian lebih atas risiko kecurangan. Melalui struktur corporate governance, tone at the top, penentuan tujuan yang realistis dan kebijakan serta prosedur yang dapat mencegah tindakan penyimpangan. Pendapat lain mengemukakan: " $A$ control system that meets these requirements provides reasonable assurance that the organization's goals and objectives will be met and that fraud will be reduced, prevented, and deterred" (Albercht, 2012).

Adapun rumusan masalah yang diajukan, yaitu : (1) Bagaimana pelaksanaan risk based internal auditing ?, (2) Bagaimana gambaran pencegahan fraud ?, (3) Bagaimana pengaruh pelaksanaan risk based internal auditing terhadap pencegahan fraud?

\section{METODE PENELITIAN}

Menurut Arikunto (2010:90), metode penelitian adalah rencana atau rancangan sebagai ancar-ancar kegiatan yang akan dilaksanakan. Metode yang digunakan dalam penelitian ini adalah metode deskriptif. Menurut Sugiyono (2012), "penelitian deskriptif ini dilakukan untuk mengetahui nilai variabel atau lebih (independent) tanpa membuat perbandingan, atau menghubungkan dengan variabel lain". Dalam penelitian ini, penulis melakukan penelitian dengan menggunakan metode survei. Menurut Sugiyono (2012:11), metode survei digunakan untuk mendapatkan data dari tempat tertentu yang alamiah, tetapi peneliti melakukan perlakuan dalam pengumpulan data, misalnya dengan mengedarkan kuesioner, test, wawancara terstruktur dan sebagainya.

Populasi dalam penelitian ini yaitu auditor internal Kantor Inspeksi Bank BRI Wilayah Bandung.Sampel dalam penelitian ini berjumlah 27 industri yang diambil dengan menggunakan metode sampel jenuh.Sampling jenuh menurut Sugiyono (2008:96), teknik penentuan sampel, dimana semua anggota populasi digunakan sebagai sampel.

Pengumpulan data untuk keperluan penyusunan skripsi ini dilakukan dengan mengunakan kuesioner, yaitu teknik pengumpulan data dengan mengajukan serangkaian pertanyaan tertulis mengenai hal-hal yang berkaitan dengan masalah yang diteliti kepada responden.Seluruh pertanyaan yang terdapat dalam kuesioner digunakan untuk mengetahui persepsi pegawai mengenai manfaat pelaksanaan risk based internal audit terhadap pencegahan fraud.

Analisis data yang digunakan dalam penelitian ini adalah dengan analisis regresi linear sederhana.Data kemudian diolah menggunakan metode statistik dengan menggunakan software SPSS (Statistik Product and Service Solution).Peneliti melakukan terlebih dahulu uji asumsi klasik sebelum melakukan pengujian hipotesis. 


\section{HASIL DAN PEMBAHASAN}

Hasil penelitian yang dilakukan oleh peneliti berdasarkan studi lapangan dengan menyebarkan kuesioner pada auditor internal Kantor Inspeksi / KANINS Bank BRI wilayah Bandung.Pembahasan penelitian ini mengacu pada rumusan masalah yang diajukan. Untuk mengetahui bagaimana pelaksanaan risk based internal audit tersebut, peneliti menggunakan metode interpretasi skor sehingga diperoleh kriteria. Dari hasil perhitungan pelaksanaan risk based internal audit diperoleh total skor sebesar 1670. Skor tertinggi adalah 80 yang diperoleh dari item pernyataan no. 1, yakni pada indikator tahap perencanaan audit.Hal ini mengambarkan bahwa dalam menghadapi setiap tugasnya, audit internal Kantor Inspeksi Bank BRI wilayah Bandung selalu membuat perencanaan yang sistematis untuk semua penugasan yang akan dilaksanakan. Sedangkan skor terendah adalah 67 yang diperoleh dari item pernyataan no.12 yakni pada indikator avoiding / penghindaran risiko namun hasil interpretasi dari indikator avoiding / penghindaran risiko termasuk dalam kategori baik / efektif. Hal ini menggambarkan dalam penghidaran risiko audit internal Bank BRI dapat merancang ulang proses sedemikian rupa sehingga menghilangkan risiko khusus, atau menghindari aktivitas yang risikonya tidak dapat diperkecil sampai tingkat yang dapat diterima. Adapun tingkat interpretasi pelaksanaan risk based internal audit yang diperoleh dengan membandingkan hasil dengan total skor tertinggi mendapatkan hasil sebesar 80,67\%,tingkat interpretasi pelaksanaan risk based internal audit secara keseluruhan adalah 80,67\% termasuk dalam kategori baik/efektif. Hasil tersebut mengindikasikan bahwa pelaksanaan risk based internal audit pada audit internal Bank BRI Kantor Wilayah Bandung telah terlaksana dengan baik/efektif.

Untuk mengetahui bagaimana pencegahan fraud tersebut, peneliti menggunakan metode interpretasi skor sehingga diperoleh kriteria.Dari hasil perhitungan pencegahan fraud diperoleh total skor sebesar 1132. Skor tertinggi adalah 78 yang diperoleh dari item pernyataan no. 24, 26, dan 37. Yakni pada indikator menyusun dan mengkomunikasikan kode etik, mempekerjakan orangorang yang jujur, dan hukuman.Mayoritas responden memberikan jawaban pada skala "4 dan 5" terhadap tiga item pernyataan tersebut.Hal ini membuktikan bahwa Kantor Inspeksi Bank BRI Wilayah Bandung telah mengkomunikasikan kode etik dan menegakan aturan dengan baik/efektif. Sedangkan skor terendah sebesar 72 diperoleh dari item no 30 yakni indikator menciptakan lingkungan kerja yang positif. Mayoritas responden memberikan jawaban pada skala "4" terhadap item pernyataan tersebut.tingkat penilaian menciptakan lingkungan kerja yang positif termasuk dalam kategori baik/efektif, namun dalam rekapitulasi kuesioner indikator ini mendapat nilai terendah dibanding indikator yang lainnya. Hal ini membuktikan bahwa dalam menghadapi setiap tugasnya, audit internal Kantor Inspeksi Bank BRI wilayah Bandung telah memberikan pengakuan yang adil dan objektif atas kinerja pekerjaan serta dapat menciptakan lingkugan kerja 834 | Jurnal Riset Akuntansi dan Keuangan Vol.3 | No.3 | 2015 
yang positif namun masih dirasa kurang optimal, aman, dan nyaman. Albrecht (2012:118) menjelaskan ketika nilai sosial dan perilaku organisasi tidak kondusif terjadi seperti manajemen yang reaktif, agresif, pemarah, mudah menuruti kata hati, tidak berperasaan, emosional, tidak ada komunikasi terbuka dan tulus akan menimbulkan apatisme, ketidakpedulian, kegusaran, dan kekecewaan yang juga dapat mendorong rasionalisasi fraud. Untuk tingkat interpretasi pencegahan fraud secara keseluruhan adalah 83,85\% termasuk dalam kategori baik/efektif. Hasil tersebut mengindikasikan bahwa pencegahan fraud pada audit internal Bank BRI Kantor Wilayah Bandung telah terlaksana dengan baik/efektif.

Untuk mengetahui adanya pengaruh antara variabel tersebut, peneliti menggunakan korelasi regresi linear sederhanaterlebihdahulu untukmengetahui keterdapatan pengaruh antar variabel, kemudian dilanjutkan dengan pengujian koefisien determinasi untuk mengukur besar pengaruhnya. Dari hasil perhitungan tersebut dapat disimpulkan bahwa pelaksanaan risk based internal audit berpengaruh terhadap pencegahan fraud. Hal ini berdasarkan hasil perhitungan korelasi regrasi linear sederhana menggunakan bantuan software IBM SPSS Statistics 20diketahui koefisien korelasi untuk hipotesis ini adalah 0,296. Dengan demikian perhitungan koefisien korelasi yang dihasilkan lebih besar dari 0 (0,296 $>0$ ). Hasil tersebut mengindikasikan bahwa terdapat hubungan positif di antara kedua variabel.

Sedangkan besarnya persentase pengaruh variabel pelaksanaan risk based internal audit terhadap pencegahan fraud dapat dilihat dari koefisien determinasi, yaitu sebesar 0,088 atau $8,8 \%$. Sehingga dapat disimpulkan bahwa pelaksanaan risk based internal audit berpengaruh terhadap pencegahan fraud sebesar 8,8\%.

\section{SIMPULAN}

Berdasarkan hasil penelitian mengenai pengaruh pelaksanaan risk based internal auditing terhadap pencegahan fraud pada audit internal Kantor Inspeksi Bank BRI Wilayah Bandungdapat ditarik kesimpulan sebagai berikut:

1. Pelaksanaan risk based internal auditing pada audit internal Bank BRI Kantor Wilayah Bandung telah terlaksana dengan baik/efektif.

2. Pencegahan fraud pada audit internal Bank BRI Kantor Wilayah Bandung telah terlaksana dengan baik dan efektif. Namun salah satu indikator Organization Culture / budaya kerja yaitu menciptakan lingkungan kerja yang positif mendapat nilai terendah dibandingkan dengan indikator pencegahan fraud lainnya. Hal ini dapat dikarenakan oleh auditor internal yang merasa lingkungan kerja masih kurang optimal, aman, dan nyaman.

3. Pelaksanaa risk based internal auditing berpengaruh positif terhadap pencegahan fraud pada audit internal Kantor Inspeksi Bank BRI Wilayah Bandung. Hal tersebut membuktikan bahwa setiap peningkatan pelaksanaan risk based internal auditingakan mengakibatkan kenaikan pencegahan fraud. Hal ini sesuai dengan teori Albercht, (2012). Having a 
good system of internal control is the single most effective tool in preventing and detecting fraud.

Terdapat beberapa saran yang penulis sampaikan sehubungan dengan pelaksanaa risk based internal audit berpengaruh positif terhadap pencegahan fraud beserta hal lainnya yang terkait, yaitu:

1. Pelaksanaan risk based internal audit pada audit internal Bank BRI Kantor Wilayah Bandung telah terlaksana dengan baik/efektif, untuk menjaga hal tersebut sebaiknya manajemen memberikan pendidikan berkelanjutan atau seminar kepada auditor internal agar kualitas pelaksanaan risk based internal audit dapat efektif dan meningkat.

2. Pencegahan fraud yang dimiliki oleh Kantor Inspeksi Bank BRI Wilayah Bandung sudah sangat baik akan tetapi dilihat dari hasil penelitian yang telah diolah, bahwa dalam menciptakan lingkungan kerja yang positif masih dinilai belum cukup baik dan dapat mendorong rasionalisasi fraud, sebaiknya manajemen menindak lanjuti hal tersebut sehingga auditor internal pada Kantor Inspeksi Bank BRI Wilayah Bandung dalam melaksanakan pekerjaan dapat optimal, aman, dan nyaman. Albrecht (2012:118) menjelaskan ketika nilai sosial dan perilaku organisasi tidak kondusif terjadi seperti manajemen yang reaktif, agresif, pemarah, mudah menuruti kata hati, tidak berperasaan, emosional, tidak ada komunikasi terbuka dan tulus akan menimbulkan apatisme, ketidakpedulian, kegusaran, dan kekecewaan yang juga dapat mendorong rasionalisasi fraud.

3. Bagi peneliti selanjutnya bagi peneliti selanjutnya yang tertarik dengan permasalahan yang serupa, sebaiknya nmelakukan penelitian terhadap variabel lain dengan mengembangkan teori-teori variabel tersebut. Selain itu, dapat pula dilakukan pada Institusi lainnya yang memiliki risk based internal audit, sehingga dengan melakukan perbandingan teori-teori dan tempat lainnya tersebut maka dapat mengetahui kekurangan dan kelebihan yang ada untuk meningkatkan pencegahanfraud.

\section{DAFTAR PUSTAKA}

Albrecht, W. S. 2012. Fraud Examination. South western: Thomson

Anwar, Choirul. (2009). Risk Based Internal Auditingdan Implementasinya Pada PT IBF. Jurnal The Winners, 10 (02). ISSN 1412-1212

Arikunto, Suharsimi. (2006). Prosedur Penelitian Suatu Pendekatan Praktik.Jakarta: Rineka Cipta.

Dunil, Z. 2005. Bank Auditing Risk Based Audit Dalam Pemeriksaan Perkreditan Bank Umum. Jakarta. Indeks.

Sugiyono. 2010. Metode Penelitian Bisnis. Bandung: Alfabeta.

Singleton \& Singleton. 2010. Fraud Auditing and Forensic Accounting.Fourth Edition Wiley Corporate F\&A 